\title{
RESPON MASYARAKAT KAMPUS KEAGAMAAN TERHADAP NARASI HOAKS: TELAAH ANTROPOLINGUISTIK
}

\author{
Sultan 1 \\ Universitas Islam Negeri Mataram \\ sultan@uinmataram.ac.id
}

\begin{abstract}
Abstrak
Penelitian ini bertujuan mengklasifikasikan respon masyarakat di lingkungan kampus keagamaan terhadap narasi hoaks, dan menjelaskan potensi ancaman narsi hoaks terhadap pola keberagamaan dan keberagaman serta menjelaskan perspektif antropolinguistik terhadap narasi hoaks di lingkungan lembaga keagamaan kampus,. Metode yang digunakan dalam penelitian ini adalah metode kualitatif. Hasil dari penelitian ini: (1) Respon masyarakat di lingkungan kampus keagamaan terhadap narasi hoaks bahwa kecendrungan mereka tidak terlalu menanggapi berita hoaks terutama yang tersebar di media sosial. Hal ini menunjukkan kalangan masyarakat kampus memiliki kemampuan "memfilter" berita. Kebiasaan melakukan klarifikasi dan verifikasi merupakan hal yang positif yang menunjukkan bahwa kalangan masyarakt kampus memiliki tingkat literasi yang cukup tinggi sehingga penyebaran berita hoaks tidak serta merta menciptakan kegelisahan apalagi perdebatan yang menjurus pada konflik. (2) Potensi ancaman narasi hoaks terhadap pola keberagamaan dan keberagaman di kalangan masyarakat kampus mengindikasikan tidak begitu besar terhadap masyarakat kampus dikarenakan tingkat literasi kalangan masyarakat kampus yang cukup tinggi. (3) Antropolinguistik melihat bahwa narasi hoaks dapat menggeser dan munculkan nilai, norma dan budaya dalam lingkungan masyarakat karena bahasa memiliki hubungan yang erat dengan budaya, begitu juga budaya dapat berisikan nilai-nilai dan norma dalam kehidupan masyarakat pada sebuah bangsa dan negara.
\end{abstract}

\section{Kata Kunci : Narasi Hoaks, Kampus keagamaan dan Antopolinguistik}

\section{Pendahuluan}

Narasi hoaks merupakan mitologi gaya baru di era digital, karena dalam penyampaian informasi, orang tidak lagi berpikir apakah narasi itu kebenarannya bisa dibuktikan atau tidak, mereka cenderung mudah menerima tanpa harus melakukan konfirmasi akan kebenaran dari informasi yang didapatkan. Maka dari itu, sesuatu yang tidak dapat dibuktikan kebenaranya, secara sudut pandang antropologi 
dikatakan mitos (hoaks). Rolan Barthes ${ }^{1}$ melihat bahwa mitos sebagai ekspresi yang dapat berkembang membentuk tanda baru dan membentuk persamaan makna. Oleh sebab itu, mitos menjadi sebuah ideologi atau paradigma ketika sudah berakar lama digunakan sebagai acuan hidup dan menyentuh ranah norma sosial yang berlaku di masyarakat.

Mitologi biasanya disampaikan dengan narasi, sehingga narasi menjadi cerita terorganisir yang menggambarkan hasrat bersama untuk memecahkan masalah dan dibentuk berdasarkan ekspektasi pembaca dan penulis. Narasi hoaks terkadang bersifat ekstrem, ini ditandai dengan adanya pembedaan terhadap pihak lain, sehingga antagonisme antara kawan dan lawan serta identifikasi pihak menjadi musuh. Narasi ekstrem menganggap pihak yang berseberangan dengan nilai negatif, sekaligus memberi nilai kebaikan untuk pihak sendiri.

Narasi hoaks digunakan pengguna media sosial untuk menyampaikan informasi-informasi yang bersifat keagamaan, sosial, dan politik, narasi hoaks juga cenderung menformalistik-simbolik isu-isu yang menyangkut agama, hal ini bisa dilihat dalam perilaku bermedia sosial yang selalu mengunggah informasi hoaks. Asumsi saya, bahwa pengguna media sosial menggunakan narasi hoaks bertujuan memberikan penguatan kepada masyarakat atau orang-orang yang memiliki paradigma atau sudut pandang agama yang sama dengan mereka atau dengan istilah sederhannya penguatan idiologi di internal kelompoknya. Adapun secara eksternal, saya melihat bahwa narasi hoaks digunakan untuk melawan/memperlemah.

Pada era digital ini, narasi pemberitaan begitu cepat sampai ke tangan masingmasing warga net melalui telpon pinter, sehingga respon dan kontrol media terhadap narasi pemberitaan menjadi tidak optimal. Sementara isu-isu yang disampaikan melalui media sosial akan lebih cepat direspon dan dikirim ulang keada orang lain sehingga dalam waktu beberapa saat akan muncul respon kolektif terhadap narasi tersebut.

\footnotetext{
${ }^{1}$ Hoed, Beny, Semiotika dan Dinamika Sosial Budaya, Jakarta. Komunitas Bambu, 2011
} 
Narasi hoaks melanda semua kalangan masyarakat termasuk lembaga kampus keagaama juga tidak luput dalam memunculkan dan menyebarkan narasi-narasi hoaks. Hal ini tampak pada sebuah grup whatshap (WA), seorang anggota memosting sebuah berita tentang pemeluk agama tertentu menyerupai kostum agama lain. Postingan itu menarasikan bahwa "Telah hadir model beragama yang mirip dengan agama Islam tetapi mereka mengkaji bukan Alquran tetapi injil, mereka berjilbab menyerupai orang muslim, hati-hatilah dalam merespon agama dan mari kita jaga anak-anak kita supaya terhindar dari kesesatan." Ini adalah penggalan narasi hoaks yang diposting oleh satu anggota pada sebuah grup WA.

Hadirnya narasi seperti data di atas menggambarkan bahwa, narasi hoaks dapat melanda semua lapisan masyarakat, tidak hanya orang yang tidak berpendidikan tetapi kalangan berpendidikan juga memberikan peluang narasi hoaks untuk berkembang dangan mengirim berita yang tidak diverifikasi kebenarannya, baik secara kritis-idealis maupun verifikasi kevalidannya.

Fenomena-fenomena semacam ini menjadi ancaman dalam kehidupan sosial dan kehidupan beragama, jika tidak disertai dengan pola kekiritisan bersama dalam merespon berita hoak. Narasi hoak masalah keagamaan ini, dapat menggerus dan menggeser paradigma masyarakat tentang paham kegamaan, karena setiap informasi keagamaan, kecendrungan masyarakat menerima sebagai kebenaran yang didak harus diperdebatkan lagi.

Adapun ciri-ciri narasi hoaks, di antaranya judul berbumbu provokatif dan disertai isu-isu terkini. Kemudian tidak disertai data dan sumber yang jelas. Ini merupakan ciri umum dari narasi hoaks. Sementara hadirnya berita hoaks disebabkan lemahnya daya dan budaya literasi di kalangan masyarakat. Literasi tidak sekedar diartikan menulis dan membaca secara sederhana tetapi literasi diartikan sebagai kemampuan untuk mengidentifikasi, memahami, menerjemahkan, menciptakan, mengkomunikasikan, dan memperhitungkan dalam menggunakan bahan tertulis maupun tercetak yang berhubungan dengan konteks. Dalam konteks literasi, 
Indonesia masih tergolong menempati posisi yang tidak membanggakan, hal ini terlihat dari hasil penelitian yang dilakukan oleh Central Connectiont State University 20016, ia memaparkan bahwa Indonesia menempati rangking literasi ke 60 dari 61 negara dalam The World Most Literasi Nation. (nu.o.id. Hoaks, Literasi dan Pesan Islam, diakses pada 13/10;2017). Dari data ini, terdapat korelasi antara budaya literasi dengan budaya narasi hoaks.

Di samping rendahnya budaya literasi, penyebab lain narasi hoaks mudah dipercaya adalah karena seringnya pengulangan terhadap berita tersebut. Biasanya satu narasi hoaks akan dikirim berulang kali ke beberapa aplikasi jejaring media. Hal dapat menyebabkan seolah-olah berita tersbut benar adanya. Maka hal ini selaras dengan apa yang dikatakan Plato bahwa, kebenaran dapat dibuat dengan pengulangan kebohongan.

Dari penelusuran penulis, terdapat beberapa kajian yang membahas/menulis tentang topik ini, seperti Sella dalam tulisannya yang berjudul Pandangan Alquran terhdap realitas hoaks, ia menyebutkan bahwa, Makna hoax sebagaimana yang telah disebutkan oleh ahli tafsir khususnya dalam Surat An-Nur ayat 11-19 adalah suatu fitnah atau tuduhan, hoax juga merupakan konspirasi untuk mengalahkan lawan atau musuh, dan juga sifat hoax sendiri adalah berita yang cepat menyebar dan mampu memengaruhi(Afrilia et al., n.d.) Kemudian Lina Meilita Rahayu menjelaskan dalam tulisannya Memahami Teks Menangkal Hoaks, ia menyebutkan bahwa kekuatan masyarakat di bidang literasi dan multiliterasi belum baik, oleh sebab itu ia menawarkan solusi peningkatan budaya literasi melalui pembelajaran.(Rahayu, Budaya, \& Padjadajaran, 2012) syaiful Ilham juga meneliti tentang Fenomena Hoaks di Media Sosial dalam Pandangan Hermenetik, ia menyimpulkan bahwa, hoak bisa didekati melalui pendekatan hermeneutik dengan mengaplikasikan pendekatan fiksasi dan distansisi, dengan dua pendekatan ini pembaca dapat mengidentifikasi kebenaran sebah berita di media sosial.(FENOMENA HOAX DI MEDIA SOSIAL DALAM PANDANGAN HERMENEUTIKA, n.d.) Sementara topik yang saya bahas dalam 
penelitian ini adalah penelitian yang dilakukan di lembaga kampus kegamaan di Kalimantan Barat yang difokuskan pada kampus keagaaman, hal ini dikarenakan, kalimantan barat adalah propinsi yang memiliki masyarakat hetrogen. Hetrogenitasnya terlihat latar belakang masyarakat yang tidak seragam, seperti agama, suku, budaya, dan bahasa. Oleh sebab itu riset ini sangat tepat untuk dilakukan untuk mengidentifikasi sejak dini supaya perselisihan di bidang agama yang disebabkan oleh narasi narasi hoak menjadi sesuatu yang penting. Dari uraian latar belakang ini, masalah yang akan dibahas adalah Bagaimanakah respon masyarakat di lingkungan kampus keagamaan terhadap narasi hoaks? Bagaimanakah potensi ancaman narsi hoaks terhadap pola keberagamaan dan keberagaman?dan Bagaimanakah perspektif antropolinguistik terhadap narasi hoaks di lingkungan lembaga keagamaan kampus?

\section{Metode Penelitian}

Metode merupakan strategi telaah ilmiah yang berorientasi pemerolehan data dengan kegunaan tertentu. Metode yang digunakan dalam penelitian ini adalah metode kualitatif dengan pendekatan analisis internal kebahasaan (mikro linguistik), dan antropolingusitik (makro linguistik). Studi mengenai bahasa atau mengenai pemakaian bahasa, dimaksudkan untuk menggambarkan tata pemakaian kalimat, dan membongkar maksud dan makna tertentu dalam bahasa bahasa hoaks. Penelitian ini menggunakan data berupa (1) teks-teks yang bersumber dari media sosial: facebook, whats App, dan media sosial lainya. (2) hasil wawancara dengan dosen dan mahasiswa kampus keagamaan.Teknik pengumpulan data dalam penelitian ini menggunakan pola purposip sampling. Adapun teknik analisis data dilakukan dengan teknik deskriptif. 


\section{Pembahasan}

\section{Respon masyarakat di lingkungan kampus keagamaan terhadap narasi hoaks}

\section{Definisi Berita Hoaks Menurut Masyarakat Kampus}

Secara umum, hoaks dapat didefinisikan sebagai berita bohong yang sengaja disebarkan untuk tujuan tertentu. Berdasarkan hasil wawancara yang peneliti lakukan dengan beberapa responden, kebanyakan kalangan masyarakat kampus mendefinisikan hoaks sebagai informasi yang tidak benar, berita abal-abal atau berita yang menyesatkan. Berita seperti ini marak diterima masyarakat terutama melalui media sosial dalam jaring (online) terutama Facebook karena media sdial ini sangat populer dan memiliki fitur "bagikan" sehingga dengan mudah sebuah berita atau informasi diteruskan ke pengguna lain secara instan.

Salah satu responden, AB, mendefinisikan hoaks sebagai berita provokatif karena berdasarkan pengalamannya sebagian besar isi berita hoaks yang ia terima bersifat provokatif seperti ajakan untuk melakukan demo, pemenolakan aturan atau kebijakan pemerintah, tuduhan terhadap individu atau kelompok tertentu, fitnah, pemutar-balikan fakta, penyesatan, intimidasi, penipuan dan sebagainya. Ia cukup sering menerima berita sejenis yang diteruskan orang-orang dalam lingkaran pertemanan di media sosial.

\section{Tanggapan dan Sikap Masyarakat Kampus Keagamaan terhadap Narasi}

\section{Hoaks}

Salah satu responden, MR, mengatakan ia seringkali mendapatkan berita hoaks dengan tautan ke situs berita yang awalnya sangat meyakinkan. Namun setelah ia cermati dengan mencari dan membandingkan berita yang sama di situs berita resmi, ternyata situs tersebut juga palsu. Ia menambahkan pentingnya mencermati sumber berita yang dibagikan orang di media sosial agar bisa membedakan antara berita palsu dengan berita yang terpercaya. Ia mengungkapakan beberapa teman dilingkungan tempat tinggalnya sangat mudah terpengaruh berita hoaks. Hal tersebut menurutnya disebabkan oleh keterbatasan pengetahuan dan kemampuan memilih dan 
memilah beita serta kebiasaan kebanyakan angota masyarakat yang tidak melakukan klarifikasi dan verifikasi terlebihan dahulu sebelum menerima sebuah berita. Keterbatasan akses ke duania maya juga disinyalir sebagai salah satu faktor penghambat dalam proses mencari informasi lebih lanjut. MR mengatakan ia seringkali menyaksikan orang mudah terpengaruh berita bohong karena berita tersebut didengar dari orang yang "dapat dipercaya." Menurutnya sebuah berita sapat dicurigai sebagai berita hoaks apabila isi berita tersebut bertentangan dengan logika umum. Ketika peneliti memperlihatkan postingan di Facebook kepada MR yang memperlihatkan sebuah billboard besar bertuliskan kalimat "PDI-Perjuangan tidak mebutuhkan suara umat Islam," ia nampak ragu dan bertanya, "Benar ndak ini?" Memang berita tersebut adalah berita hoaks yang betujuan untuk mendiskreditkan PDI Pejuangan karena aslinya tenyata billboard tersebut berisi himbauan tentang korupsi.

Kebanyakan responden memiliki tingkat minat baca yang cukup tinggi karena membaca merupakan salah satu hobi mereka. Sebagian responden, salah satunya adalah HS, mengungkapkan bahwa ia tidak terlaku suka membaca kecuali beritaberita menarik di media sosial. Hal ini cukup unik dimana daya tarik media sosial ternyata memberikan kontribusi terhadap minat baca seseorang. HS mengakui sering membaca di media sosial karena beritanya lebih menghebohkan sehingga ia pun tertarik untuk membacanya. Saat membaca berita di media sosial, HS kadang melakukan verifikasi kadang juga tidak tergantung jenis beritanya. Jika beritanya dianggap penting, ia segera mencari informasi lebih lanjut terkait berita tersebut, bila berita tersebut dianggap tidak penting, biasanya ia abaikan saja. Ia menuturkan biasanya ia melihat judulnya dulu. Apabila judulnya tidak terlalu penting atau menarik seperti berita tentang seekor anak kambing yang dilahirkan dengan kondisi memiliki tiga kaki, umumnya tidak dibacanya Namun apabila judul beritanya tentang bencana alam misalnya, maka ia pun tetarik untuk membaca lebih lanjut. 
Responden lainya, PA, mengungkapkan bahwa ia cukup sering membaca berita hoaks. Respon dia terhadap berita seperti itu biasanya mencari informasi lebih lanjut tentang kebenaran berita yang dibaca. Apabila berita yang dibaca tersebut ternyata tidak benar maka ia biasanya mengabaikannya. Respon seperti ini ia lakukan karena selama ini ia sudah sering mendapatkan berita bohong atau berita hoaks sehingga ia merasa jenuh dengan isi berita yang tidak jelas sumbernya. PA memilih untuk mengabaikan berita yang tidak jelas sumbernya Namun bila berita yang dibaca merupakan berita yang benar dan sudah is verifikasi kebenarannya di situs berita terpercaya lainnya seperti situs berita Kompas atau Republika, maka ia pun membagikan berita tersebut ke teman-teman lain apalagi jika berita tersebut mengandung informasi yang bermanfaat bagi orang lain.

Lain halnya dengan $\mathrm{AB}$ yang menyuakai bacaan yang berkaitan dengan hiburan, ketika menemukan berita hoaks di media sosial, ia merespon dengan sikap antipati Ia tidak suka dengan berita yang dibagikan di media sosial karena banyak sekali berita seperti yang kontennya berupa provokasi. Ia tidak menyukai berita provokatif karena ia khawatir berita semacam itu dapat kontroversi yang bermuara pada konflik, apalagi Kalimantan Barat memiliki sejarah pertikaian antar komunitas yang menelan korban jiwa dan kerugian harta benda yang tidak kecil nilainya. Menurutnya pihak berwenang harus bersikap tegas terhadap penyebar berita palsu yang sangat merugikan semua pihak. Jika terjadi perpecahan dalam masyarakat, semua pihak akan dirugikan. Hanya orang-orang tertentu yang mangambil keuntungan dengan mangail di air keruh. Dan memang, menurutnya, berita hoaks memiliki tujuan menciptakan keresahan, perpecahan bahkan pertikaian dalam masyarakat yang tentunya bersifat destruktif. Hal ini sangat merugikan dan mengancam persatuan dan kesatuan bangsa.

Sebagai mahasiswa, RY sering menggunakan internet atau lebih spesifik media sosial untuk mendapatkan informasi terkini. Menurutnya media sosial sangat bermanfaat terumata untuk berkomunikasi dengan teman-teman di SMP dan SMA 
dulu sehingga persahabatan merka bisa terus terjalin. Ketika ditanya tentang berita hoaks di media sosial, ia mengatakan bahwa ia sering menemukan berita bohong disana. Uniknya, ia tidak melakukan klarifikasi atau verifikasi terhadap berita seperti itu. Menurutnya saat ini di media sosial sangatbanyak beredar berita tidak benar, jadi jika berita yang ditemukan tidak masuk akal, ia tidak menggubrisnya. Ketika ditanyakan lebih jauh mengenai responnya terhadap berita seperti itu, ia mengaku lelah membaca posting yang dibagikan teman-temannya yang isinya tidak bisa dipercaya. Ia pun tidak pernah membagi berita di media sosial karena "takut kena batunya." Ia mengatakan bahwa ia sadar akan adanya Undang-Undang mengenai cyber-crime. Tentu saja ia tidak mau berurusan dengan pihak berwajib hanya garagara mebagikan berita tidak benar. Ia mengakui bahwa ia pernah mambagikan berita yang didapatkan dari teman di media sosial kepada pengguna lainnya. Namun yang ia bagikan biasanya cerita lucu. Untuk konten yang berbau politik atau SARA sama sekali tidak pernah ia teruskan kepada pengguna lain, cukup menjadi konsumsi sendiri saja.

Sebaliknya IR, seorang mahasiswa di Fakultas Syariah IAIN Ponianak, jarang membaca berita di media sosial karena selain alasan keterbatasan akses internet yang ia miliki, ia mengaku bahwa lebih suka membaca berita seputar olah raga terutama sepak bola dan Moto GP (turnamen balap sepeda motor). Saat ia terkoneksi ke dunia maya, biasanya ia mencari berita tentang olah raga yang menurutnya jauh lebih positif membacanya ketimbang berita di media sosial. Kadang ada juga berita di media sosial yang ia baca, dan ia sering melakukan klarifikasi dengan menanyakan perihal berita tersebut ke teman2nya. Ketika ditanya tentang responya, ia menjawab, "Biasa-biasa saja." Karena saat ini menurutnya banyak sekali berita yang simpang siur sehingga ia tidak mau menanggapi secara berlebihan.

Dari serangkaian wawancara yang peneliti lakukan dengan beberapa responden dari kalangan masyarakat kampus, rata-rata mereka tidak terlalu menanggapi berita hoaks terutama yang tersebar di media sosial. Hal ini 
menunjukkan kalangan masyarakat kampus memiliki kemampuan "memfilter" berita dimana apabila berita yang sedang menjadi trend di media sosial yang banyak dibagikan ke sana sini segera mereka cari sumbernya. Kebiasaan melakukan klarifikasi dan verifikasi merupakan hal yang positif yang menunjukkan bahwa kalangan masyarakt kampus memiliki tingkat literasi yang cukup tinggi sehingga penyebaran berita hoaks tidak serta merta menciptakan kegelisahan apalagi perdebatan yang menjurus pada konflik.

\section{Potensi Ancaman Narasi Hoaks terhadap Pola Keberagamaan dan Keberagaman}

Tingkat literasi yang cukup tinggi di kalangan masyarakat kampus merupakan salah satu benteng yang sangat penting dalam menangkal ancaman berita bohong atau hoaks. Hasil wawancara yang peneliti lakukan dengan responden menunjukkan bahwa sebagian besar dari mereka tidak mudah terpengaruh berita yang belum jelas sumbernya atau dengan kata lain para responden dalam penelitian ini tidak terlalu menanggapi berita hoaks yang mereka dapatkan di media sosial meskipun di luar kalangan kampus seperti di kampung salah satu responden sebagian aggota masyarakatnya sangat mudah terpengaruh berita palsu. SY mengungkapkan bahwa di kampungnya sebagian anggota masyarakat kecewa dengan Presiden Joko Widodo karena memilih Ma'ruf Amin sebagai calon wakil presiden untuk bertarung do Pemilu 2019. Kekecewaan tersebut, menurut SY, disinyalir akibat berita hoaks yang menyebutkan bahwa ulama dimanfaatkan untuk kepentingan politik dalam hal ini agar incumbent bisa terpilih kembali.

Kejadian lain juga diungkapkan oleh SY bahwa di kampungnya banyak anggota masyarakat yang tidak senang dengan pemberitaan bahwa PDI Perjuangan tidak membutuhkan suara umat Islam. Berita tersebut jelas berita bohong alias hoaks. Peneliti melakukan penelusuran dan mendapatkan postingan di Facebook yang menampilkan sebuah baliho besar yang menyebutkan bahwa Ketua Umum PDI 
Perjuangan mengatakan bahwa Partainya tidak membutuhkan suara umat Islam. Konten baliho tersebut sudah diedit oleh pihak tertentu dimana aslinya isi baliho tersebut merupakan ajakan untuk mencegah tindak pidana korupsi. Lebih jauh SY mengungkapkan bahwa sebuah berita patut dicurigai sebagai berita hoaks bila berita tersebut terskesan janggal atau tidak lazim. Ia mencontohkan apabila ia menerima berita yang sedang viral di media sosial tentang seorang dokter yang mengatakan bahwa merokok itu menyehatkan, maka berita seperti itu bisa dicurigai sebagai berita bohong karena bertentangan dengan kelaiman dan pengetahuan umum bahwa merokok dapat menyebabkan berbagai macam masalah kesehatan.

Menurut SY, tingkat literasi masyarakat yang masih minim seperti di kampungnya merupakan sasaran empuk bagi penyebar berita hoaks. Apalagi kebiasaan sebagian masyarakat disana tidak memeriksa kembali atau melakukan klarifikasi saat menerima berita yang kadang secara logika tidak masuk akal. Misalnya, sebuah partai politik seperti PDI Perjuangan tidak membutuhkan suara kelompok masyrakat tertentu sangat tidak masuk akal. Partai politik sangat membutuh suara dari berbagai pihak untuk bisa eksis dan berkembang. Oleh sebab itu HS, salah satu responden, memiliki alasan yang kuat saat ia mengatakan bahwa berita di media sosial kadang sangat negatif dan bagi orang yang belum berpengalaman di dunia maya, mendapat berita serupa akan menjadi masalah. Di kalangan masyarakat kampus, hal ini tidak terlalu mengkhawatirkan karena sebagian besar responden yang wawancarai peneliti mengatakan bahwa mereka selalu mencari informasi lebih lanjut tentang sebuah berita bila timbul keraguan. Kebiasaan melakukan klafikasi merupakan cara yang cukup efektif untuk melakukan filtrasi / menyaring berita sebelum dipercaya atau diteruskan lagi ke pengguna lainnya.

Seringnya berita hoaks dibagikan melalui media sosial menyebabkan sebagian responden merasa jenuh. $\mathrm{AB}$ misalnya tidak menyukai berita yang dibagikan oleh teman-temannya di media sosial karena sebagaian besar isinya provokatif. Responden 
lain, RY, juga mengungkapkan hal senada dimana ia merasa 'capek' dengan berita yang heboh di Facebook dan bersikap apatis.

Hasil wawancara dengan responden di kalangan masyarakat kampus mengindikasikan bahwa ancaman narasi hoaks terhadap keberagamaan dan keberagaman tidak begitu besar terhadap masyarakat kampus walaupun ada potensi perpecahan terhadap pola keberagaman, dikarenakan beberapa hal sebagai berikut: pertama Tingkat literasi kalangan masyarakat kampus yang sudah cukup tinggi karena sebagian besar memiliki hobi atau kebiasaan membaca yang cukup tinggi. Kedua Melakukan verifikasi atau setidaknya mencari informasi lebih lanjut. Ketiga kejenuhan terhadap berita hoaks karena terlalu sering menerima berita serupa. Keempat ecenderungan mengabaikan berita yang tidak jelas sumbernya. Kelima presumsi bahwa berita yang dibagikan di media sosial banyak yang tidak benar.

\section{Perspektif Antropolinguistik terhadap Narasi Hoaks di Kalangan Masyarakat Kampus Keagamaan}

Dari berbagai jenis struktur dan tema narasi hoaks telah yang peneliti kemukakan pada tabel di atas, berikut peneliti akan menguraikan tafsir antropolinguiastik terhadap narasi hoaks tersebut. Narasi hoaks merupakan informasi yang berisikan beirta yang tidak benar. Ketidakbenaran ini didasrakan atas terjadinya perbedaan antara konten yang disampaikan dengan fakta yang sebenarnya, oleh sebab itu peran antropolinguistik sebagai kajian interdisipliner; antara kajian bahasa dan budaya sangan penting untuk mengungkap makna dan tujuan dihadirkan berita berita (narasi) hoaks di kalangan masyarakat.

Antropolinguistik mengkaji narasi hoaks melalui beberapa bagian kajian. Pertama antropolinguistik mengkaji pada lapisan teks, dan konteks, hal ini bertujuan untuk mengungkapkan struktur, dan formula masing-masing. Kedua antropolinguistik mengkaji seluk-beluk nilai dan norma budaya yang diinterpretasikan berdasarkan makna, pesan, dan fungsinya, dari munculnya budaya narasi hoaks di kalangan 
masyarakat. Ketiga antropolinguistik mengkaji pergeseran nilai dan budaya yang disebabkan oleh keberadaan penyebaran narasi hoaks di kalangan masyarakat. Keempat, antropolinguistik mengkaji proses dan pola untuk menanggulangi merebaknya budaya pemunculan berita bohong (hoaks) di kalangan masyarakat terutama di kalangan masyarakat kampus, yang menurut pandangan analisis wacana kritis disebut dengan prakik berwacana, seperti produksi, distribusi, dan konsumsi teks yang secara berkelanjutan dalam masyarakat. Keempat model kajian antropolingustik tersebut, akan penulis jadikan acuan untuk menelaah narasi hoaks di kalangan masyarakat kampus, berikut penulis akan menguraikan secara terperinci.

\section{Narasi hoaks dari sudut konstruksi: teks dan konteks.}

\section{a. Teks narasi hoaks}

Teks merupakan komponen utuh yang mengandung makna dalam sebuah wacana. Konteks tidak hanya berupa kata dan kalimat tetapi dapat berupa kata atau frasa. Teks memiliki posisi yang tidak dapat dipisahkan dari makna. Konstruksi teks narasi hoak seperti pada data berikut.

, Untuk para rekan guru diharapkan kerja sama nya juga apabila murid keluar kelas jika belum dijemput tolong bantuan nya untuk mengawasi murid nya. Untuk orangtua jika menjemput harus nya lebih awal datangnya sebelum jam sekolah di bubarkan.

Ungkapan pada teks tersebut saling melengkapi dengan adanya timbal balik penyerta. Teks pertama menginformasikan, dan teks kedua menganjurkan atau mengharapkan agar munculnya tidakan atas sebuah kejadian. Di antara kedua teks tersebut terdapat ko-teks yang menjadi penghubung munculnya timbal balik.

\section{b. Kontek narasi hoaks}

Konteks merupakan sesuatu yang menyertai saat aktifitas berbahasa, konteks juga menjadi aspek penyerta secara fisik atau sosial dalam suatu ujaran atau teks yang 
muncul. Konteks dapat menjadi penyebab terjadinya suatu dialog pada sebuah komunikasi, baik lisan maupun tulisan. Dalam sebuah wacana atau narasi, memiliki keterkaitan unsur-unsur dalam satu konteks untuk dipahami bersama. Konteks dalam narasi hoaks meliputi beberapa kondisi seperti yang terdapat pada masing-masing data (narasi hoaks) pada penjabaran berikut ini.

Pada data (I) konteksnya adalah menjelaskan bahwa penculikan anak merupakan salah satu topik hangat yang sangat menarik perhatian masyarakat. Tidak mengherankan hoaks yang bertemakan penculikan anak bisa langsung viral di dunia maya dan inilah yang diinginkan oleh penyebarnya. Dengan teknologi edit gambang yang semakin canggih, tema penculikan anak begitu mudah direkayasa dengan menggunakan aplikasi picture editing yang mudah didapat serta mudah digunakan. Salah satu hoaks yang peneliti cermati bernarasi " seorang siswa SD tersebut telah diculik lalu dimasukkan ke dalam mobil pelaku". Tentu saja hal ini sangat meresahkan masyarakat. Kejadian ini bermula dari sebuah Sekolah Dasar di daerah Depok yaitu SD Al Khariyah Cilodong. Dalam pesan yang beredar viral di media sosial, disebut bahwa seorang anak Sekolah Dasar diculik lalu dimasukkan ke dalam mobil pelaku. Untungnya pihak Kepolisian melalui PLH Kasubbag Humas Polresta Depok Firdaus segera meluruskan berita hoaks tersebut dengan mengatakan bahwa tidak ada penculikan anak seperti yang disampaikan dalam pesan berantai di media dalam jaringan (online). Ia menjelaskan bahwa pihak kepolisian telah mendatangi sekolah yang disebutkan dalam berita hoaks tadi dan bertemu dengan sejumlah guru dan kepala sekolahnya. Salah seorang guru di SD tersebut menegaskan bahwa berita penculikan tersebut tidak benar dan hal yang sama juga disampaikan oleh Kepala Sekolah SD Al Khariyah, yang langsung berkoordinasi dengan para guru kelas dan beliau mengatakan bahwa seluruh siswa didiknya lengkap dan kembali ia tegaskan tidak ada pencuikan yang terjadi.

Pada data (II) dijelaskan bahwa Khabib Nurmagomedov, seorang petarung MMA (Mixed Martial Arts) asal Rusia sedang naik daun. Terakhir ia memenangkan 
pertarungan bergengsi melawan Conor McGregor dengan kemenangan KO. Khabib merupakan serang petarung Muslim yang sangat dibanggakan penggemarnya terutama dari kalangan Muslimin. Beredar foto yang langsung viral dimana Khabib bersama mantan juara tinju kelas berat dunia, Mike Tyson, --yang juga serang muallaf-- mengenakan topi dan baju dengan lafaz tauhid.

Dalam narasi foto tersebut terdapat sebuah klaim bahwa beredarnya foto Khabib dan Tyson menggunakan topi dan kaos bertuliskan kalimat tauhid seolah mengindikasikan bahwa mereka anggota Hizbut Tahrir Indonesia (HTI). "Apakah Khabib dan Mike Tyson itu anggota HTI?" demikian pertanyaan yang mengikuti foto tersebut. Namun faktanya bahwa kedua petarung tersebut hanya mengenakan topi dan baju biasa dan tidak ada tulisan tauhidnya. Foto ini muncul di akun Facebook milik pengguna dengan nama Prayoga Budhi dan sudah dibagikan sebnyak 6192 kali.

Pada data (III) dikemukakan bahwa kasus korupsi sering menimpa pejabat public yang kemudian diblow-up oleh media sehingga sebuah kasus menjadi perbincangan khalayak ramai. Kali ini muncul berita Pemanggilan Kapolri Jendral Tito Karnavian oleh KPK terkait keterlibatan beliau dalam tindak pidana korupsi penerimaan suap petinggi CV Sumber Laut Perkasa yang menyeret pengusaha Basuki Hariman dan mantan menteri Hukum dan Hak Asasi Manusia, Patrialis Akbar, saat Tito menjabat sebagai Kapolda Metro Jaya. Sebuah foto yang memperlihatkan sebuah surat pemanggilan KPK yang ditujukan terhadap Kapolri Jenderal Tito Karnavian. Dalam surat tersebut, Kapolri disebutkan terlibat tindak pidana korupsi penerimaan suap petinggi CV Sumber Laut Perkasa yang menyeret Basuki Hariman dan Patrialis Akbar, saat Tito Karnavian menjabat sebagai Kapolda Metro Jaya.

Dalam konteks ini, antropolinguistik memandang bahwa narasi hoaks atau penyebaran berita bohong sebagai suatu usaha untuk mempengaruhi psikologis (kejiwaan) lawan tutur dalam hal ini pembaca yang berdampak pada pemunculan respon yang dapat menjadi budaya baru di kalangan masyarakat. Hal ini selaras dengan apa yang disampaikan oleh Von Humboldt bahwa bahasa merupakan aktivitas 
rokhani artinya, bahasa merupakan aktifitas kejiwaan yang berulang-ulang untuk membentuk ide gagasan dengan mengeluarkan bunyi artikulasi yang mencerminkan lambang jiwa, tabiat (kebiasaan) sifat suatau bangsa. Oleh sebab itu narasi hoaks apabila disampaikan secara berulang kali, akan berpotensi menjadi informasi yang diyakini memiliki nilai kevalidan, hal ini akan terjadi apabila lawan tutur atau pembaca/ penerima pesan tidak melakukan pengecekan berita yang sama dari sumber yang berbeda, namun malah membagikan kembali kepada orang lain.

\section{Pemunculan dan Pergeseran Nilai, Norma, dan Budaya Berdasarkan Narasi Hoaks di Kalangan Masyarakat.}

Bahasa memiliki hubungan yang erat dengan budaya, begitu juga budaya dapat berisikan nilai-nilai dan norma dalam kehidupan masyarakat pada sebuah bangsa dan negara. Sementara setiap bangsa berbicara dengan cara dia berpikir dan pemikiran sesuai dengan cara dia berbicara. Pikiran tidak dapat dialihkan dari satu bahasa ke bahasa lain, karena setiap pikiran itu memiliki formulasi. Adapun dari sudut pandang behavioris disebutkan bahwa seyogyanya setiap orang di kalangan masyarakat mengucapkan sesuatu sesuai dengan apa yang dia lakukan dan melakukan sesuai dengan apa yang diucapkan.

Dari pandangan ini dapat dipahami bahwa, muncul dan berkembangnya narasi hoaks di kalangan masyarakat dapat melunturkan nilai kebersamaan selama ini, seperti etika berkomunikasi, atau sopan santun dalam berbahasa. Narasi hoak juga dapat memunculkan beberapa hal yang menyangkut nilai, norma dan budaya.

a. Budaya berbagi

Budaya berbagi dalam konteks ini adalah tindakan menyebarkan informasi yang belum terverifikasi kebenaran baik oleh diri sendiri maupun oleh pihak lain. Budaya berbagi ini dilakukan dengan tujuan agar dikatakan sebagai orang yang pertama sebagai pengirim dan penyebar berita. Dalam koneks ini berbagi menjadi budaya yang tidak tepat. 
b. Munculnya polarisasi di kalangan masyarakat.

Masyarakat yang awalnya hidup rukun, damai penuh persaudaraan dan persatuan, namun terkadang gara-gara penyebaran narasi hoaks yang begitu masip dapat mengakibatkan runtuhnya persatuan dan berubah menjadi kelompok-kelompok yang terpolarisasi. Kondisi semacam ini dapat mengganggu kehidupan bermasyarakat.

c. Ketidakpercayaan satau sama lain baik individu maupun kelompok, di kalangan masyarakat

Masifnya penyebaran narasi hoaks melalui media sosial dapt mengganggu rasa percaya satu sama lain, rasa percaya berubah dengan rasa saling mencurigai d. Terkikisnya budaya toleransi

Toleransi merupakan sikap untuk saling menghargai, menghormati atas segala perbedaan antara satu dengan yang lain, namun dengan beredarnya narasi hoaks dapat mengganggu toleransi yang selama ini menjadi kekuatan dalam berbangsa dan bernegara.

e. Merusak konsentrasi pembangunan bangsa

Narasi hoaks yang setiap saat menghinggapi gawai masing masing orang dapat mengganggu konsentrasi pemerintah dalam menjalankan roda pembanguan bangsa. Karena tidak jarang, narasi hoaks menjadi pemicu munculnya konflik antar perorangan dan kelompok, setiap ada konflik pemerintah harus hadir untuk menyelesaikan konflik tersebut, hal ini dapat memicu dan memecahkan konsentrasi pemerintah dalam membangun bangsa.

f. Persahabatan menjadi tercedrai.

Persahabatan yang sekian lama terjalin dapat tercedrai hanya gara-gara narasi hoaks yang disampaikan deng kurang teliti dan kurang kritis.

Beberapa poin di atas, ketika ditelaah kembali lebih mendalam dari sudut pandang antropolinguistik, bahwa hal tersebut dapat terjadi karena semua ragam bahasa yang digunakan dalam narasi hoaks menggambarkan cara berpikir masyarakatnya dan 
berbicara sesuai dengan cara berpikirnya termasuk cara-cara dalam seluk beluk kebudayaan.

\section{Simpulan}

Dari uraian pada bagian pembahasan di atas, peneliti dapat menyimpulkan bahwa (1) Respon masyarakat di lingkungan kampus keagamaan terhadap narasi hoaks bahwa kecendrungan mereka tidak terlalu menanggapi berita hoaks terutama yang tersebar di media sosial. Hal ini menunjukkan kalangan masyarakat kampus memiliki kemampuan mem-filter berita. Kebiasaan melakukan klarifikasi dan verifikasi merupakan hal yang positif yang menunjukkan bahwa kalangan masyarakt kampus memiliki tingkat literasi yang cukup tinggi sehingga penyebaran berita hoaks tidak serta merta menciptakan kegelisahan apalagi perdebatan yang menjurus pada konflik. (2) Potensi ancaman narasi hoaks terhadap pola keberagamaan dan keberagaman di kalangan masyarakat kampus mengindikasikan tidak begitu besar terhadap masyarakat kampus dikarenakan tingkat literasi kalangan masyarakat kampus yang cukup tinggi. (3) Antropolinguistik melihat bahwa narasi hoaks dapat menggeser dan munculkan nilai, norma dan budaya dalam lingkungan masyarakat karena bahasa memiliki hubungan yang erat dengan budaya, begitu juga budaya dapat berisikan nilai-nilai dan norma dalam kehidupan masyarakat pada sebuah bangsa dan negara.

\section{Daftar Pustaka}

Afrilia, S., Triana, R., Alumni, S. R., Al-Hidayah, S., Tetap, D., Al, S., \& Bogor, H. (n.d.). Pandangan Al-Qur'an Terhadap Realitas Hoax.

\section{FENOMENA HOAX DI MEDIA SOSIAL DALAM PANDANGAN HERMENEUTIKA.} (n.d.).

Rahayu, L. M., Budaya, F. I., \& Padjadajaran, U. (2012). Memahami Teks , Menangkal Hoaks : Understanding Texts, Preventing Hoaxes : 
Arifin, Zaenal. 2009. Cermat Berbahasa Indonesia Untuk Perguruan Tinggi. Jakarta: Akademika Presindo

Duranti, Alesandro. 1997. Lingustic Antropology. Massachusetts. Blacwell.

Endaswara. 2006. Metodologi Penelitian Kebudayaan. Yogyakarta. Uniiversitas Gadjah Mada.

Goleman, Daniel. 1997. Kecerdasan Emosional. Terjemah. T. Hermaya. Jakarta. Gramedia Pustaka.

Hoed, Beny. 2011. Semiotika dan Dinamika Sosial Budaya. Jakarta. Komunitas Bambu

Jenks, Chris. 1993. Culture: Studi Kebudayaan. Terjemah. Erika Setiawati (2013) Yogyakarta Pustaka Pelajar.

Keraf, Gorys. 2009. Diksi Dan Gaya Bahasa. Jakarta: Gramedia Pustaka Utama N.U.id. Hoaks, Literasi dan Pesan Islam. Diakses pada anggal 12 Oktober 2017. Rahardjo, Mudjia. 2004. Relung-Relung Bahasa: Bahasa dalam Wacana Politik Indonesia Kontemporer. Yogyakarta: Aditiya Media.

Palmer, Gray. 1999..

Sibarani. Robert. Toward a Theory of Cultural Linguistic. Austin: Austin University Press 1992. Hakikat Bahasa. Bandung: Citra Aditiya Bakti. 2004. Antropolinguistik: Antropologi Linguistik dan Linguistik Antropologi. Medan: penerbit Popda.

Afrilia, S., Triana, R., Alumni, S. R., Al-Hidayah, S., Tetap, D., Al, S., \& Bogor, H. (n.d.). Pandangan Al-Qur'an Terhadap Realitas Hoax.

FENOMENA HOAX DI MEDIA SOSIAL DALAM PANDANGAN HERMENEUTIKA. (n.d.).

Rahayu, L. M., Budaya, F. I., \& Padjadajaran, U. (2012). Memahami Teks , Menangkal Hoaks : Understanding Texts, Preventing Hoaxes : 
Sudaryanto. 2004. Metode dan Teknik Penelitian Bahasa. Yogyakarta. Unversitas Gadjah Mada Press

Thomas dan Wearing. 2007. Bahasa, Masyarakat \&Kekuasaan. Penerj. Sunoto dkk. Yogyakarta; Pustaka Pelajara.

Widjono. 2008. Bahasa Indonesia. Jakarta: Grasindo 